\title{
Leaf pigments and chlorophyll fluorescence patterns in leaves of mango as affected by low temperature degrees under field and laboratory conditions
}

\begin{abstract}
Low temperature is a major environmental and evolutionary driver that limits the geographical distribution of plant species worldwide. The relationship between low temperature stress and the response of some different mango cultivars was monitored on some physiological and biochemical events that occur following cold exposure of mango trees leaves. These changes were studied under in vitro (controlled temperatures). However, mango trees were tested to study the changes in leaf pigments and chlorophyll fluorescence of some mango cultivars in response to exposure to low temperature. To verify this objective, 12 popular commonly mango cultivars ( 25 years old) which grown in private orchard in Fayoum Governorate, Egypt were selected for this study which carried out during the period from November to March of years; 2012 and 2013. The selected cultivars were: Alphonso, Baladi, Bullock's Heart, Helmand, Hindi Besennara, Mabrouka, Mestekawy, Nabeeh, Oweisi, Spates, Taimour and Zebda. Based on the obtained results, it can be stated that in cold storage trial; It was found that chlorophyll (a) level was the highest by Spates cultivar and the lowest one by the cultivar of Mabrouka at storage of $5^{\circ} \mathrm{C}$ and $10^{\circ} \mathrm{C}$ as well. Chlorophyll (b) level was the highest by the cultivar of Spates and the minimum one by Ewais cultivar at $5^{\circ} \mathrm{C}$ of storage while, the cultivars of Spates and Mabrouka given the highest and lowest level at $10^{\circ} \mathrm{C}$ of storage, respectively. Total chlorophyll values in leaves reached its maximal by the cultivar of Spates and the minimal by Mabrouka at $5{ }^{\circ} \mathrm{C}$ and $10^{\circ} \mathrm{C}$ of storage. The obtained results explained that the level of carotenoids reached its peak at $5^{\circ} \mathrm{C}$ and $10^{\circ} \mathrm{C}$ of storage by the cultivars of Hindy Besennara and bullock's Heart, respectively. While, the lowest one was recorded by the cultivars of Zebda and Helmand, respectively. The levels of anthocyanin in leaves were significantly differed as affected by the cultivars and storage, indicating that the cultivars of Ewais and Taimour showed the highest levels of anthocyanin and the lowest ones were recorded by the cultivars of Zebda and Alphonso at $5^{\circ} \mathrm{C}$ and $10^{\circ} \mathrm{C}$ of storage, respectively. It can be seen that the highest decline in $F v / F m$ ratio were given by the cultivar of Balady while, the higher ratio was recorded by Nabeeh cultivar at $5^{\circ} \mathrm{C}$ of storage. At $10^{\circ} \mathrm{C}$ of storage, Nabeeh cultivar gave the highest ratio of $F v / F m$ and the lowest one was obtained by Mestekawy one. A noticeable decline in $F v / F m$ values was observed as storage period $\left(5^{\circ} \mathrm{C}\right.$ and $\left.10^{\circ} \mathrm{C}\right)$ was progressed reaching the minimum level by day 10 of storage.
\end{abstract}

Keywords: mango, cultivars, cold tolerance, leaf pigments, chlorophyll fluorescence
Volume 4 Issue I - 2020

\author{
Farouk M Gadallah,' Mohamed A Seif El- \\ Yazal,' Gamal A Abdel-Samad, ${ }^{2}$ Ali A Sayed' \\ I Botany Department, Faculty of Agriculture, Fayoum University, \\ Egypt \\ 2 Horticulture Department, Faculty of Agriculture, Fayoum \\ University, Egypt
}

Correspondence: Mohamed A Seif El-Yazal, Botany Department, Faculty of Agriculture, Fayoum University, Fayoum 635।4, Egypt, Email mas0@fayoum.edu.eg

Received: December 17, 2019 | Published: January 31, 2019

\section{Introduction}

Mango (Mangifera indica L.) is a popular, national tropical fruit, which is now one of the most important fruits crops in tropical and subtropical areas of the world. ${ }^{1}$ Mango occupies third place in total world production of major tropical fruit crops after citrus and banana. $^{2}$ Environmental conditions outside the traditional areas for optimum growth of mango may impose stresses, which can result in physiological changes, reduced growth, or even permanent damage to the trees. ${ }^{3,4}$ Low temperature is acknowledged to be one of the most dominant environmental stresses that affect the growth, productivity and geographical distribution of plants., ${ }^{5,6}$ Exposure to low; nonfreezing temperatures induces genetic, morphological, metabolic and physiological changes in plants, which result in the development of cold hardiness and acquisition of freezing tolerance. ${ }^{7-9}$ A mango need an optimum temperature range of $24-26.7^{\circ} \mathrm{C}$ and minimum threshold temperature is $10-12^{\circ} \mathrm{C}$ below this plant shows chilling injury. ${ }^{10,11}$ Mango trees show high susceptibility to low temperature $\left(0-15^{\circ} \mathrm{C}\right)$. Young trees are damaged by low temperature variability among cultivars is apparent after a cold spell, but precise information on this subject is non-existent. ${ }^{12,13}$ The decline of photosynthetic capacity in low temperature is related to a decrease in the quantum efficiency of PSII. ${ }^{10} \mathrm{He}$ added that, Photosynthetic apparatus PSII is the primary target of damage under low temperature. ${ }^{14}$ showed that coffee plants resulted in 30\% reduction in Chlorophyll a, 27\% reduction in Chlorophyll b, $29 \%$ reduction of total Chlorophyll when night temperature decreasing from $20^{\circ} \mathrm{C}$ to $8^{\circ} \mathrm{C}$. Also in $O$. sativa, the total Chlorophyll content was reduced by $50 \%$ due to exposure to low temperature $\left(10^{\circ} \mathrm{C}\right)$ for 2 weeks. ${ }^{15}$ In Carplants, $86 \%$ reduction of $\alpha$-carotene, $57 \%$ reduction in $\beta$-carotene, $68 \%$ reduction in $\alpha / \beta$ carotene ratio. ${ }^{15}$ The anthocyanin concentrations in both apple and peach shoots increased rapidly during cold acclimation reaching the peak value in early December. The anthocyanin may be accumulated in shoots as a result of leucoanthocyanidin conversion. ${ }^{16}$ Anthocyanin 
accumulation in green leaves is mainly induced by environmental stresses such as low temperatures. ${ }^{17}$ anthocyanins also function as antioxidants, helping maintain toxic reactive oxygen species at low steady-state levels in plants exposed to cold stress. ${ }^{18}$ This is consistent with previous studies indicating that anthocyanin accumulation in green leaves and stems is mainly induced by environmental stresses such as low temperatures and high light. A twofold accumulation of anthocyanins was observed in winter oilseed rape leaves grown in low temperatures for 3 weeks, which was hypothesized to act as a filter that shielded the mesophyll from excessive radiation. ${ }^{19}$ It has been reported that chlorophyll $\mathrm{a}, \mathrm{b}$ and carotenoids content was decreased in plants when subjected to cold treatment. The proportion of closed PSII reaction centers increases as low temperature decreases the rate of photosynthesis. Low temperature also inhibits the rate at which PS II is repaired..$^{20}$ At temperatures lower than $10^{\circ} \mathrm{C}$, the effects are more pronounced because also membrane-bound chlorophyll may be destroyed by free radicals of oxygen despite the protective action of carotenoids. ${ }^{21}$ Chlorophyll fluorescence of PSII plays an important role in the response of leaf photosynthesis to environmental stresses. ${ }^{22}$ The technique measures changes in chlorophyll $a$ fluorescence due to altered photosystem II (PSII) activity, caused directly or indirectly by stress. ${ }^{23}$ Ratios of the parameters $F v / F m, F o$, and $F v / F o$ provide estimates of various aspects of leaf photosynthetic and photochemical activities. ${ }^{24,25} \mathrm{Fv} / \mathrm{Fm}$ measurements from 0.78 to 0.85 are associated with healthy, non-stressed deciduous and evergreen trees. ${ }^{26} \mathrm{The} F v / F m$ ratios for leaves of mango trees were $0.80 \pm 0.03$, for indicating that the photosynthetic processes were functioning normally in autumn. ${ }^{27}$ The $\mathrm{Fv} / \mathrm{Fm}$ ratios for mango trees were lower in winter when minimum daily temperatures decreased below $10{ }^{\circ} \mathrm{C}$ compared to early fall when chilling did not occur. The lower $F v / F m$ ratios indicated a reduced photochemical conversion efficiency of PSII, ${ }^{28}$ which can be an effect of photoinhibition at chilling temperatures. ${ }^{29}$ The use of chlorophyll Fluorescence measurements as a screening method for cold tolerance has already been investigated in experiments in which genotypes were compared. ${ }^{30,31}$ Chlorophyll fluorescence has been used as a non-intrusive indicator of in vivo photosynthetic reactions and environmental stresses ${ }^{32}$ of various crop plants. Thus, chlorophyll fluorescence is an indirect measurement of the physiological status of green tissues. ${ }^{33-35}$ Chlorophyll fluorescence has been used to evaluate injuries caused by low temperatures in mango, ${ }^{36}$ cucumber $^{37}$ and apples. ${ }^{38,39}$ Decline in chlorophyll fluorescence in mango is related to the loss of chlorophyll content and chloroplast competence. ${ }^{36}$ The ratio of $F v / F m$ has an optimal value of 0.83 . When exposed to abiotic and biotic stresses, $F v / F m$ in plants will decrease. ${ }^{40}$ This parameter is therefore frequently used as a stress detector under environmental stress conditions, such as temperature. ${ }^{41}$ So, CF has been widely used to detect physiological status of plants under different abiotic stress, for example in the presence of nitrogen deficiency, cold and drought. ${ }^{42}$ Yet, research on the physiological basis of cold tolerance of mango has received more attention. Here we attempt to check the changes in leaf pigments and chlorophyll fluorescence that occur following cold exposure.

\section{Materials and methods}

A trial was independently conducted during 2012 and 2013, in a private orchard, Fayoum, Egypt, located at $29^{\circ} 22^{\prime} \mathrm{N}$ and $30^{\circ} 47^{\prime} \mathrm{E}$. and in the laboratory of Agricultural Botany Dept., Faculty of Agric., Fayoum University. The experiment assess to evaluate the cold tolerance of some mango cultivars grown under Fayoum Governorate conditions and check the changes in leaf pigments and chlorophyll fluorescence that occur following cold exposure.

\section{Climate of experiment site}

At the site of experiment, temperatures fluctuated during the duration of study and five years before the beginning of the study. In this respect, the mean monthly maximum temperature $\left(\mathrm{T}_{\mathrm{Max}}\right)$ ranging from about $17.7^{\circ} \mathrm{C}$ in January 2008 to about $40.2^{\circ} \mathrm{C}$ in August 2010 and the fluctuation in mean monthly minimum temperature $\left(\mathrm{T}_{\text {Min }}\right.$ ) was ranging from about $5.7^{\circ} \mathrm{C}$ in January $2007 / 2008$ to about $25.2^{\circ} \mathrm{C}$ in August 2012. An extreme minimum temperature of $0.6^{\circ} \mathrm{C}$ was recorded in January 2008; however, there were large differences between the selected years (Table 1).

Table I The Monthly mean of maximum and minimum temperatures (open air-temperature) during the period from January 2006 to March 20 I 3

\begin{tabular}{llllllllll}
\hline MontlH2/-year & Temp. & 2006 & 2007 & 2008 & 2009 & 2010 & 2011 & 2012 & 2013 \\
\hline January & Max. & 19 & 19 & 18 & 21 & 22 & 21 & 20 & 23 \\
\multirow{2}{*}{ February } & Min. & 7 & 6 & 6 & 7 & 8 & 8 & 7 & 10 \\
& Max. & 22 & 21 & 20 & 22 & 24 & 22 & 22 & 24 \\
March & Min. & 8 & 8 & 7 & 6 & 8 & 9 & 8 & 10 \\
& Max. & 26 & 25 & 29 & 23 & 28 & 26 & 25 & 29 \\
April & Min. & 10 & 10 & 12 & 8 & 11 & 10 & 12 & 13 \\
& Max. & 30 & 29 & 32 & 31 & 32 & 29 & 29 & \\
May & Min. & 13 & 13 & 14 & 13 & 14 & 14 & 14 & \\
June & Max. & 33 & 35 & 35 & 33 & 34 & 33 & 34 & \\
& Min. & 17 & 18 & 18 & 17 & 17 & 17 & 18 & \\
& Max. & 37 & 39 & 39 & 38 & 38 & 36 & 38 & \\
& Min. & 20 & 21 & 22 & 20 & 21 & 21 & 22 & \\
\hline
\end{tabular}


Table continue

\begin{tabular}{llllllllll}
\hline MontIH2/-year & Temp. & $\mathbf{2 0 0 6}$ & $\mathbf{2 0 0 7}$ & $\mathbf{2 0 0 8}$ & $\mathbf{2 0 0 9}$ & $\mathbf{2 0 1 0}$ & $\mathbf{2 0 1 1}$ & $\mathbf{2 0 1 2}$ & $\mathbf{2 0 1 3}$ \\
\hline July & Max. & 37 & 39 & 38 & 39 & 36 & 39 & 40 & \\
& Min. & 21 & 22 & 22 & 23 & 22 & 22 & 24 & \\
August & Max. & 38 & 38 & 39 & 37 & 40 & 39 & 38 & \\
& Min. & 22 & 22 & 22 & 22 & 25 & 23 & 25 \\
September & Max. & 35 & 34 & 36 & 35 & 36 & 36 & 35 \\
& Min. & 20 & 21 & 20 & 21 & 22 & 22 & 23 \\
October & Max. & 31 & 32 & 32 & 32 & 36 & 30 & 34 \\
& Min. & 17 & 18 & 17 & 18 & 21 & 18 & 22 \\
November & Max. & 24 & 27 & 27 & 25 & 31 & 27 & 28 \\
& Min. & 11 & 13 & 13 & 12 & 17 & 13 & 16 \\
December & Max. & 20 & 21 & 22 & 22 & 24 & 22 & 22 \\
& Min. & 8 & 8 & 9 & 9 & 10 & 10 & 11 \\
\hline
\end{tabular}

*Data applied by Bureau of meteorology, agriculture ademonstration, fayoum governorate, Egypt

\section{Plant materials}

The plant materials comprised 12 mango cultivars which collected from their natural growing location in the period of November 2012 to march 2013. This is approximately the time at which the cold hardiness may be occurring. Mango trees were about 25 years old, planted in a clay soil at $5 \times 5 \mathrm{~m}$ apart. The cultivars were used in this study including most of the popular cultivars which grown in Fayoum Governorate. The tested cultivars were, Alphonso, Baladi, Bullock's Heart, Helmand, Hindi Besennara, Mabrouka, Mestekawy, Nabeeh, Oweisi, Spates, Taimour, and Zebda.

\section{Laboratory trial (cold storage)}

Studying cold tolerance in the field is difficult. Fields sites often exhibit either complete survival or complete winter kill. Because of this variability, the laboratory procedures to measure cold tolerance have been developed by a number of investigators ${ }^{43,44}$. The results have usually been in a good agreement with field observations of natural cold injury. ${ }^{45}$ At $30^{\text {th }}$ of November, the mature fully expanded leaves of each cultivar were collected, cleaned, washed and toweled dry then putted in a vinyl plastic bags and subjected to various low temperature treatments. In this respect, the collected leaves from each cultivar were divided in two batches; each one was composed of 10 leaves in three replicates. These batches were stored in a refrigerator at $5^{\circ} \mathrm{C}$ and $10^{\circ} \mathrm{C}$ in darkness and ten leaves were taken from each batch (three replicates) per cultivar every 2 days up to 10 days. Samples from these leaves were selected for physiological and biochemical studies. All treatments were applied in a factorial randomized complete block design with three replicates.

\section{Leaf pigments and Carotenoids estimation}

Chlorophyll ( $\mathrm{mg} \mathrm{g}^{-1} \mathrm{FW}$ ) were estimated adopting the procedure given by. ${ }^{46} 100 \mathrm{mg}$ of leaf sample from different cultivars were collected and homogenized in $25 \mathrm{ml}$ of $80 \%$ acetone using mortar and pestle. The optical density of the acetone extract was measured at 663, 645 and $452 \mathrm{~nm}$ using visible recording spectrometer (Spectronic 20, Bausch \& lamb). Amount of chlorophyll a, b, total chlorophyll and total Carotenoids are calculated as follows:
Chlorophyll $\quad(\mathrm{A})=[(12.7 \times \mathrm{E} 663)-(2.69 \quad \mathrm{E} 645)] \times 0.25\left(\mathrm{mg} \quad \mathrm{g}^{-1}\right)$ Chlorophyll $(\mathrm{B})=[(22.4 \times \mathrm{E} 645)-(4.68 \times \mathrm{E} 663)] \times 0.25\left(\mathrm{mg} \mathrm{g}^{-1}\right)$

Total Chlorophyll $=[(8.02 \times \mathrm{E} 663)+(20.2 \times \mathrm{E} 645)] \times 0.25\left(\mathrm{mg} \mathrm{g}^{-1}\right)$ Carotenoids $=\left[(4.57 \times\right.$ E452) $-(0.226 \times$ Total Chl $)] \times 0.25\left(\mathrm{mg} \mathrm{g}^{-1}\right)$

\section{Determination of otal Anthocyanin}

Anthocyanin was determined colorimetrically in mango leaves according to Fuleki and Francis ${ }^{47}$ as follows:

$0.1 \mathrm{~g}$ from grounded leaves were macerated with ethanol $95 \%$ and HCL $1.5 \mathrm{~N}(85: 15 \mathrm{v} / \mathrm{v})$ and filtered using a vaccum pump. The absorbency of extracted solution was measured at $535 \mathrm{~nm}$ using spectrophotometer (Spectronic 20 Boasch \& lamb) acidified ethanol was used as the blank absorbance. Anthocyanin content was calculated in absolute quantity with the aid of the extinction coefficient (E1\%1 $\mathrm{cm} 535$ value for anthocyanin 98.2) established for the anthocyanin dissolved in the alcoholic solvent system mentioned. The total Anthocyanin is calculated using the following equation:

Total Anthocyanin mgs per 100g. $={\mathrm{O} . \mathrm{D}_{535}} \times \mathrm{DW} \times 100 / \mathrm{SW} \times 1 / 98.2$

Where $\mathrm{O} . \mathrm{D}=$ the optical density of the diluted sample.

$\mathrm{DV}=$ Diluted volume as the volume in mls of the diluted extract prepared for O.D measurements.

$\mathrm{SW}=$ sample weight in grams.

\section{Chlorophyll fluorescence assay (CF assay)}

At a room temperature, leaf chlorophyll fluorescence (CF) measurements were conducted on the mature fully expanded leaves of each tree using a portable pulse amplitude-modulated fluometer (Handy PEA, Hansatech Instruments Ltd, Kings Lynn, UK). Fluorometer was used to obtain the minimal and maximal CF (F0 and $\mathrm{Fm}$, respectively), Variable $\mathrm{CF}(\mathrm{Fv}=\mathrm{Fm}-\mathrm{F} 0)$, and potential (maximum) quantum yield of PsII $(\mathrm{Fv} / \mathrm{Fm})$ (terminology according to Van Kooten and Snel. ${ }^{48}$ This ratio is used as an indicator of plant photosynthetic performance with optimal values around (0.83). ${ }^{35}$ Before measuring CF parameters, Leaves were put in dark-adapted state for 20 min by 
attaching light exclusion clips to leaf surfaces in situ. Exitation light of $650 \mathrm{~nm}$ (Peak wave length) from a array of three light- emitting diodes is focused on the surface of the leaf to provide a homogenous illumination. Light intensity reaching the leaf was $3000 \mu \mathrm{molm}^{-2} \mathrm{~s}^{-1}$ which was sufficient to generate maximal fluorescence for all the treatments. In all cases, ten leaves (the same developmental stage) were chosen per tree and a total of 30 measurements per treatment were made. Assessment was made at 2 days intervals for cold storage treatment and monthly for the field samples.

\section{Statistical analysis}

All data were subjected to analysis of variance (ANOVA) using the statistical software package of Genstat (version 11) (VSN International Ltd., Oxford, UK). Means comparison among the different treatments was performed using the least significant differences procedure (LSD) at the $P \leq 0.05$ level as illustrated by. ${ }^{49}$

\section{Results}

The results of one season were discussed because no significant differences were observed between results of the studied seasons.

\section{Laboratory trial (Cold storage)}

\section{1-Leaf pigments}

Based on the results obtained here it can be state that leaf pigments content of different mango cultivars leaves were affected by low temperature either as degree or period of exposure.

\section{Chlorophyll a (Chl.a).}

Regarding to the effect of low temperature on Chl.a content of different cultivars (Table 2), it is notice that Chl.a concentration was significantly differed among the most of cultivars throughout the whole storage period at $5^{\circ} \mathrm{C}, 10^{\circ} \mathrm{C}$. In this respect, at storage of $5^{\circ} \mathrm{C}$, the highest value of Chl.a was recorded by spates cultivar and the lowest one was given by the cultivar of Mabrouka. At storage of leaves at $10^{\circ} \mathrm{C}$, the highest value of Chl.a was also shown by spates cultivar and the lowest one was recorded by the cultivar of Mabrouka one. Here, the data shown that there is no a trend in the concentration of Chl.a with the progress of storage period or degree of temperature as well as comparing with leaf Chl.a concentration in zero time.

Table 2 Chlorophyll (a) concentration ( $\mathrm{mg} \mathrm{g}^{-1} \mathrm{FW}$ ) in leaves of some mango cultivars leaves after exposure to low temperature degrees $\left(5^{\circ} \mathrm{C}\right.$ and $\left.10^{\circ} \mathrm{C}\right)$ at various storage periods ( 2 to 10 days)

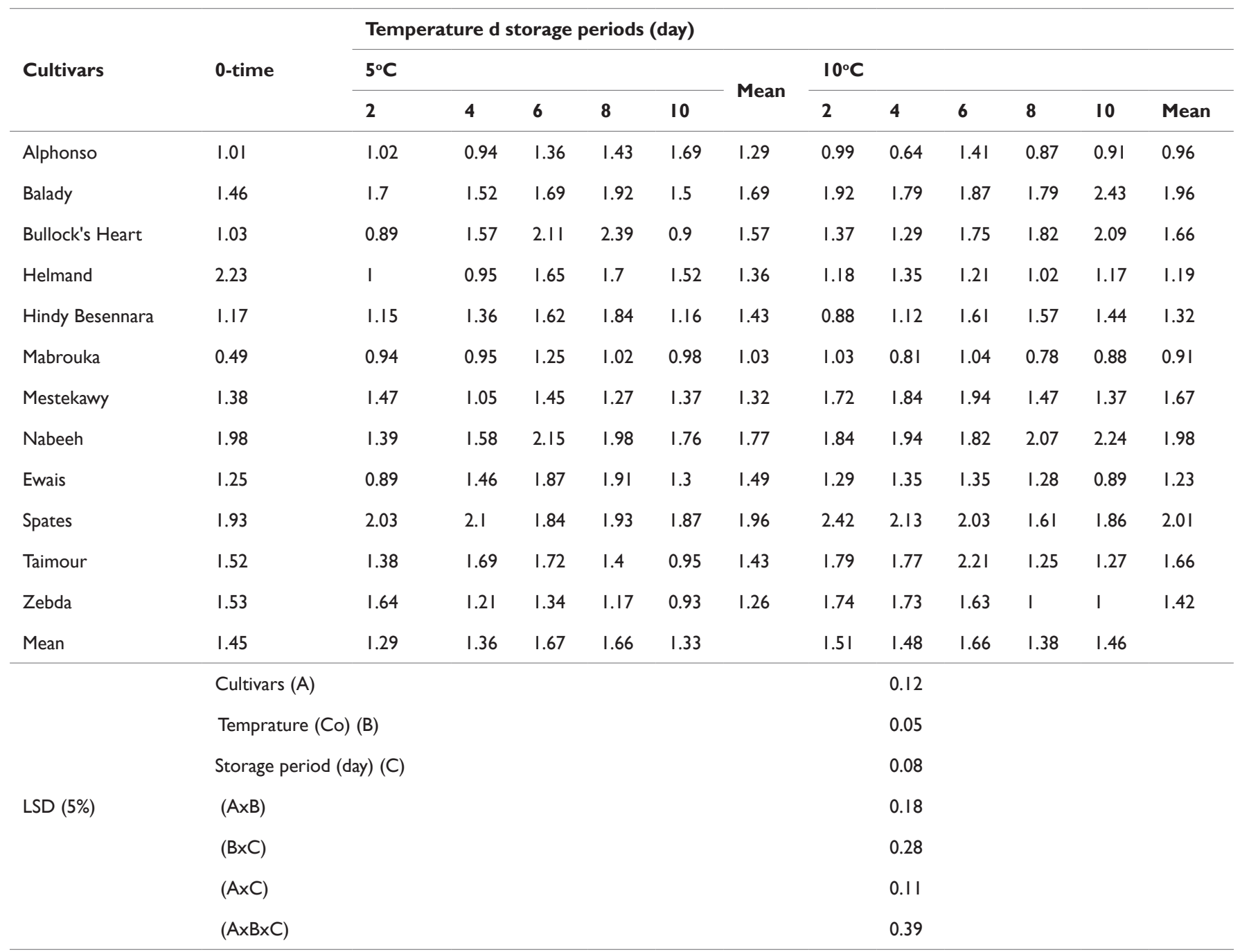




\section{Chlorophyll b (Chl.b).}

The changes in Chl.b concentration in stored mango leaves at different temperature degrees are shown in (Table 3). Results obtained at storage of $5^{\circ} \mathrm{C}$ show that, at storage of $5^{\circ} \mathrm{C}$, the cultivar of spates recorded the highest concentration of Chl.b while, the lowest one was given by the cultivar of Ewais. At storage of $10^{\circ} \mathrm{C}$, the highest concentration of Chl.b was recorded by the cultivar of spates while, the lowest one was obtained by Mabrouka one. However, Chl.b concentration was significantly differed among the cultivars during the whole degrees storage period under the different degrees of temperature. Moreover, it can be noticed that leaf Chl.b concentration has not a pattern between the intervals of storage at $5^{\circ} \mathrm{C}$ and a similar trend was recorded to that exhibited by the stored leaves at $10^{\circ} \mathrm{C}$.

\section{Total chlorophyll (T.Chl.).}

The influence of leaves storage at different degrees of temperature on T.chl. is demonstrated in (Table 4) which shows that leaves storage at temperature of $5^{\circ} \mathrm{C}$ or $10^{\circ} \mathrm{C}$ resulted in significant differences among the tested cultivars were recorded during the whole storage period under the different degrees of temperature $\left(5^{\circ}\right.$ or $\left.10^{\circ} \mathrm{C}\right)$. However, the highest value of T.chl. at temperature of $5^{\circ} \mathrm{C}$ was exhibited by the cultivar of spates and the lowest one by Mabrouka cultivar. While, at temperature of $10^{\circ} \mathrm{C}$, the cultivar of spates gave the highest value of T.chl. and the lowest value was detected by Mabrouka cultivar. The data indicate also that, the concentration of leaf T.chl. under storage of $5^{\circ} \mathrm{C}$ take the same trend of T.chl. concentration in stored leaves at $10^{\circ} \mathrm{C}$, all of them have not any trend in between the periods of storage.

Table 3 Chlorophyll (b) concentration ( $\mathrm{mg} \mathrm{g}^{-1} \mathrm{FW}$ ) in leaves of some mango cultivars leaves after exposure to low temperature degrees $\left(5^{\circ} \mathrm{C}\right.$ and $\left.10^{\circ} \mathrm{C}\right)$ at various storage periods ( 2 to 10 days)

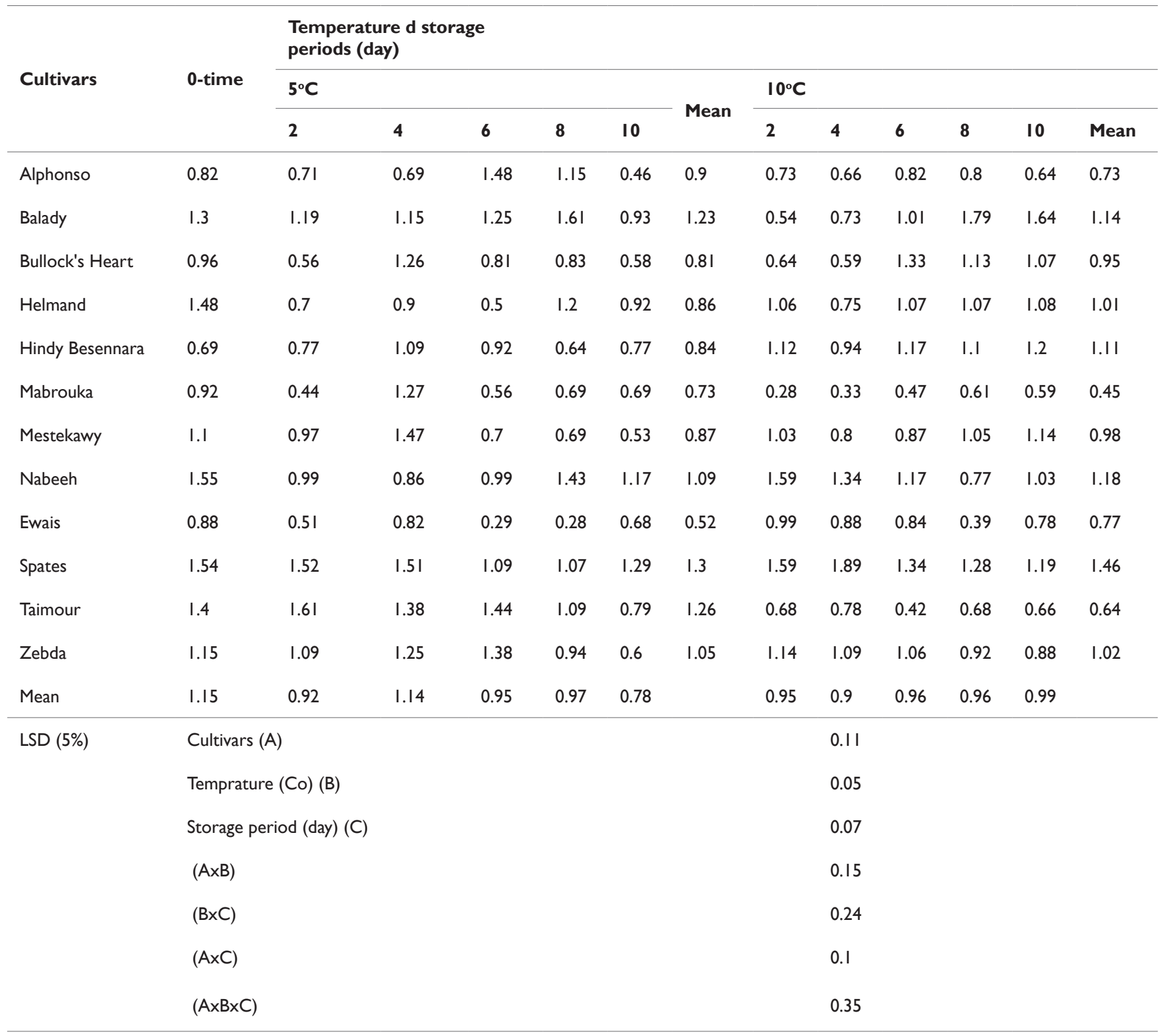


Table 4 Total chlorophyll concentration $\left(\mathrm{mg} \mathrm{g}^{-1} \mathrm{FW}\right)$ in leaves of some mango cultivars leaves after exposure to low temperature degrees $\left(5^{\circ} \mathrm{C}\right.$ and $\left.10^{\circ} \mathrm{C}\right)$ at various storage periods ( 2 to 10 days)

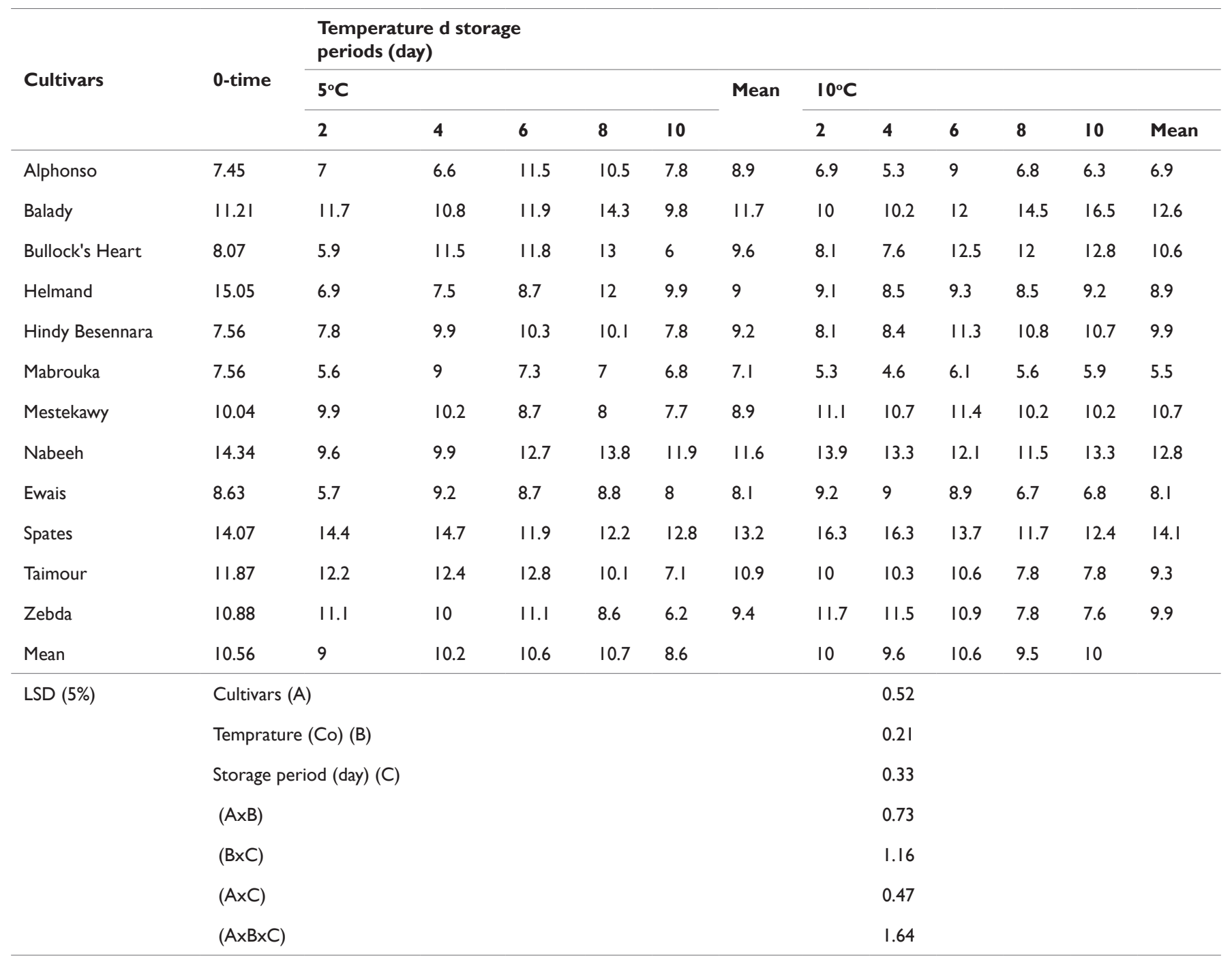

\section{Carotenoids}

The changes in carotenoids concentration in stored leaves of mango cultivars at different degrees of temperature are shown in (Table 5). Results obtained explain that the concentration of carotenoids reached its maximum level at the temperature of $5^{\circ} \mathrm{C}$ by the cultivars of Hindy Besennara and Zebda and the lowest was recorded by the cultivar of Bullock's Heart. At the temperature of $10^{\circ} \mathrm{C}$, the concentration of carotenoids in leaves reached its maximum level by Zebda cultivar while, the minimum level was recorded by Helmand one. However, the values of carotenoids were significantly differed among the lowest of the tested cultivars under the different degrees of storage. In addition, the obtained results show that the pattern of change in the concentration of carotenoids along the periods of storage under $5^{\circ} \mathrm{C}$ and $10^{\circ} \mathrm{C}$ was not consistent.

\section{Anthocyanin}

The results in Table 6 indicate the differences in anthocyanin concentration significant between the studied cultivars under the condition of experiment. In this respect, Ewais cultivar showed the highest value in anthocyanin concentration as compared to the others. While, the lowest value was recorded by Zebda cultivar during the storage at temperature of $5^{\circ} \mathrm{C}$. The cultivar of Taimour showed higher anthocyanin concentration than those recorded by the others and the lowest one was obtained by Alphonso. However, the period of exposing mango leaves to low temperature of $5^{\circ} \mathrm{C}$ and $10^{\circ} \mathrm{C}$ had a significant effect between the most periods and zero time but without consistent pattern.

\section{2- Chlorophyll fluorescence (CF)}

Results in Table 7 showed that the greatest reduction in $F v / F m$ at the temperature of $5^{\circ} \mathrm{C}$ was exhibited by the cultivar of Balady while, the higher value of $F v / F m$ was obtained by Nabeeh cultivar. However, the values of $F v / F m$ ranging from $0.045-0.436$. At the temperature of $10^{\circ} \mathrm{C}$, the cultivar of Nabeeh given the highest value of $\mathrm{Fv} / \mathrm{Fm}$ while, the lowest one was obtained by the Mestekawy cultivar. The values of $F v / F m$ ranging from 0.009 to 0.726 . Generally, the $F v / F m$ was affected by storage temperature and vary significantly with cultivars.

At the same time, all the cultivars under the periods of storage gave the lower values in comparing with zero time when leaves exposed to $5^{\circ} \mathrm{C}$ or $10^{\circ} \mathrm{C}$. In addition, a noticeable decrease in $F v / F m$ values was observed as storage period $\left(5^{\circ} \mathrm{C}\right.$ or $\left.10^{\circ} \mathrm{C}\right)$ was progressed reaching the minimum level by day 10 . 
Table 5 Carotenoids concentration $\left(\mathrm{mg} \mathrm{g}^{-1} \mathrm{FW}\right)$ in leaves of some mango cultivars leaves after exposure to low temperature degrees $\left(5^{\circ} \mathrm{C}\right.$ and $\left.\mathrm{I} 0^{\circ} \mathrm{C}\right)$ at various storage periods ( 2 to 10 days)

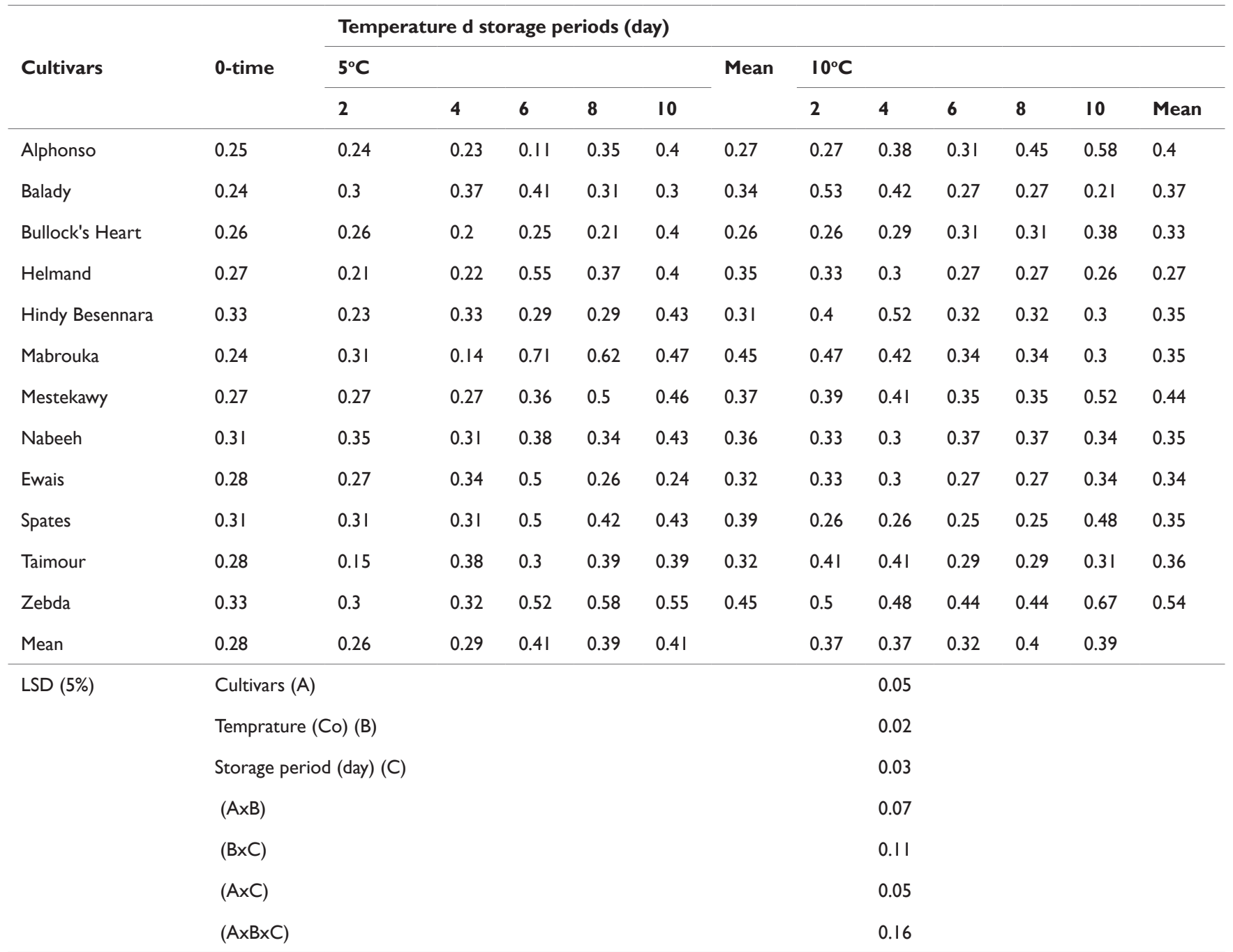

Table 6 Anthocyanin concentration $\left(\mathrm{mg} \mathrm{g}^{-1} \mathrm{FW}\right)$ in leaves of some mango cultivars leaves after exposure to low temperature degrees $\left(5^{\circ} \mathrm{C}\right.$ and $\left.10^{\circ} \mathrm{C}\right)$ at various storage periods ( 2 to 10 days)

\begin{tabular}{|c|c|c|c|c|c|c|c|c|c|c|c|c|c|}
\hline \multirow{3}{*}{ Cultivars } & \multirow{3}{*}{ 0-time } & \multicolumn{12}{|c|}{ Temperature d storage periods (day) } \\
\hline & & \multicolumn{5}{|l|}{$5^{\circ} \mathrm{C}$} & \multirow[t]{2}{*}{ Mean } & \multicolumn{6}{|l|}{$10^{\circ} \mathrm{C}$} \\
\hline & & 2 & 4 & 6 & 8 & 10 & & 2 & 4 & 6 & 8 & 10 & Mean \\
\hline Alphonso & 0.44 & 0.44 & 50 & 0.44 & $0 . .60$ & 0.74 & 0.54 & 0.3 & 0.61 & 0.42 & 0.71 & 0.86 & 0.58 \\
\hline Balady & 0.44 & 0.43 & 0.58 & 0.47 & 0.61 & 0.81 & 0.58 & 0.51 & 0.49 & 0.57 & 0.73 & 0.74 & 0.61 \\
\hline Bullock's Heart & 0.41 & 0.38 & 0.43 & 0.46 & 0.61 & 0.76 & 0.53 & 0.39 & 0.66 & 0.78 & 0.64 & 1.09 & 0.71 \\
\hline Helmand & 0.48 & 0.34 & 0.56 & 0.51 & 0.59 & 0.88 & 0.57 & 0.66 & 0.47 & 0.6 & 0.68 & 0.88 & 0.66 \\
\hline Hindy Besennara & 0.36 & 0.46 & 0.74 & 0.39 & 0.8 & 0.89 & 0.66 & 0.52 & 0.52 & 0.56 & 0.72 & 0.8 & 0.62 \\
\hline Mabrouka & 0.49 & 0.6 & 0.6 & 0.47 & 0.6 & 0.93 & 0.64 & 0.58 & 0.56 & 0.46 & 0.77 & 0.81 & 0.64 \\
\hline Mestekawy & 0.43 & 0.48 & 0.52 & 0.59 & 0.79 & 0.96 & 0.67 & 0.54 & 0.64 & 0.68 & 0.66 & 0.51 & 0.6 \\
\hline Nabeeh & $0.4 I$ & 0.42 & 0.55 & 0.61 & 0.76 & 0.87 & 0.64 & 0.55 & 0.65 & 0.47 & 0.56 & 0.97 & 0.64 \\
\hline Ewais & 0.42 & 0.56 & 0.8 & 0.47 & 0.76 & 0.94 & 0.71 & 0.52 & 0.62 & 0.51 & 0.82 & 0.84 & 0.66 \\
\hline
\end{tabular}


Table continue

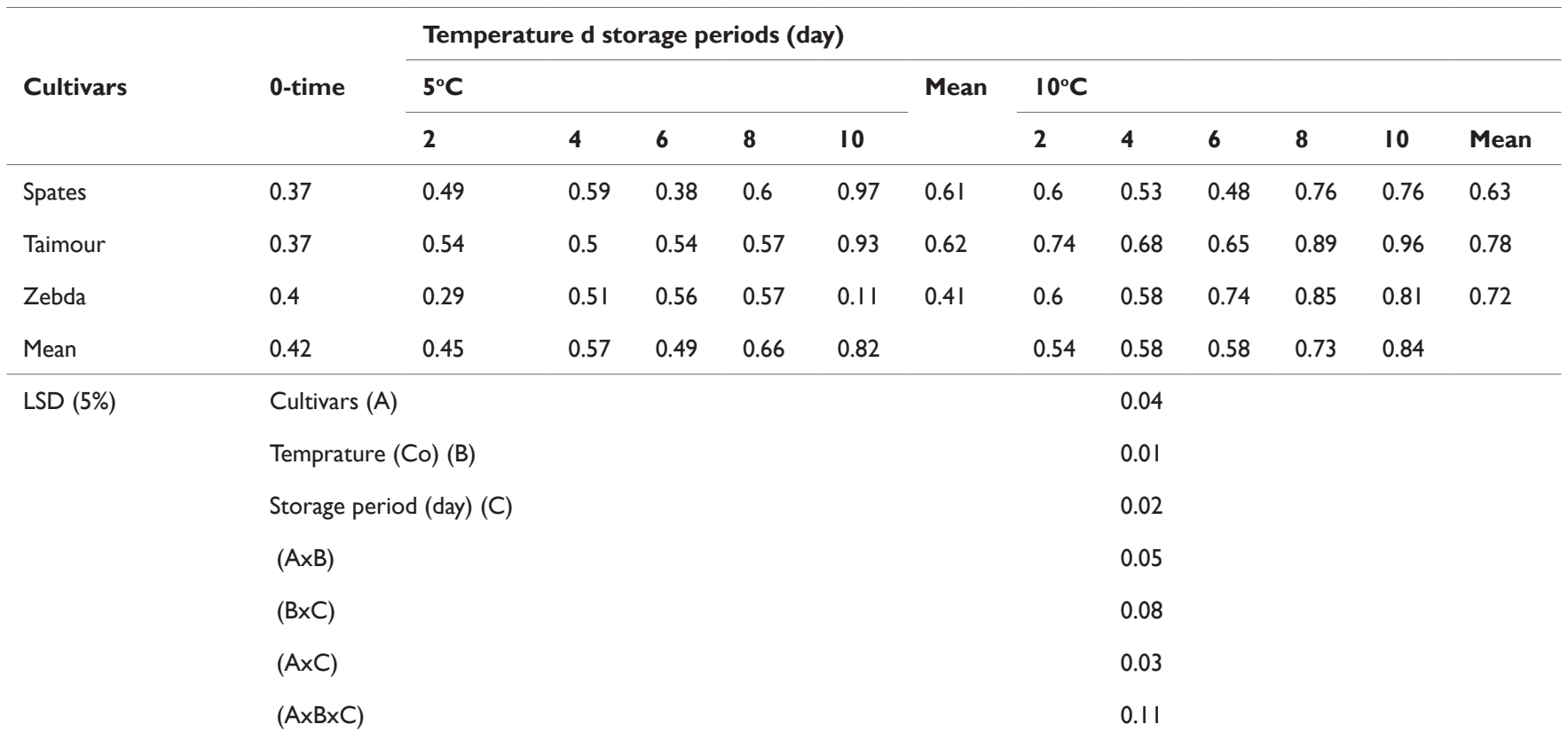

Table 7 Changes of $\mathrm{Fv} / \mathrm{Fm}$ values of chlorophyll fluorescence in leaves of some mango cultivars leaves after exposure to low temperature degrees $\left(5^{\circ} \mathrm{C}\right.$ and $10^{\circ} \mathrm{C}$ ) at various storage periods (2 to 10 days)

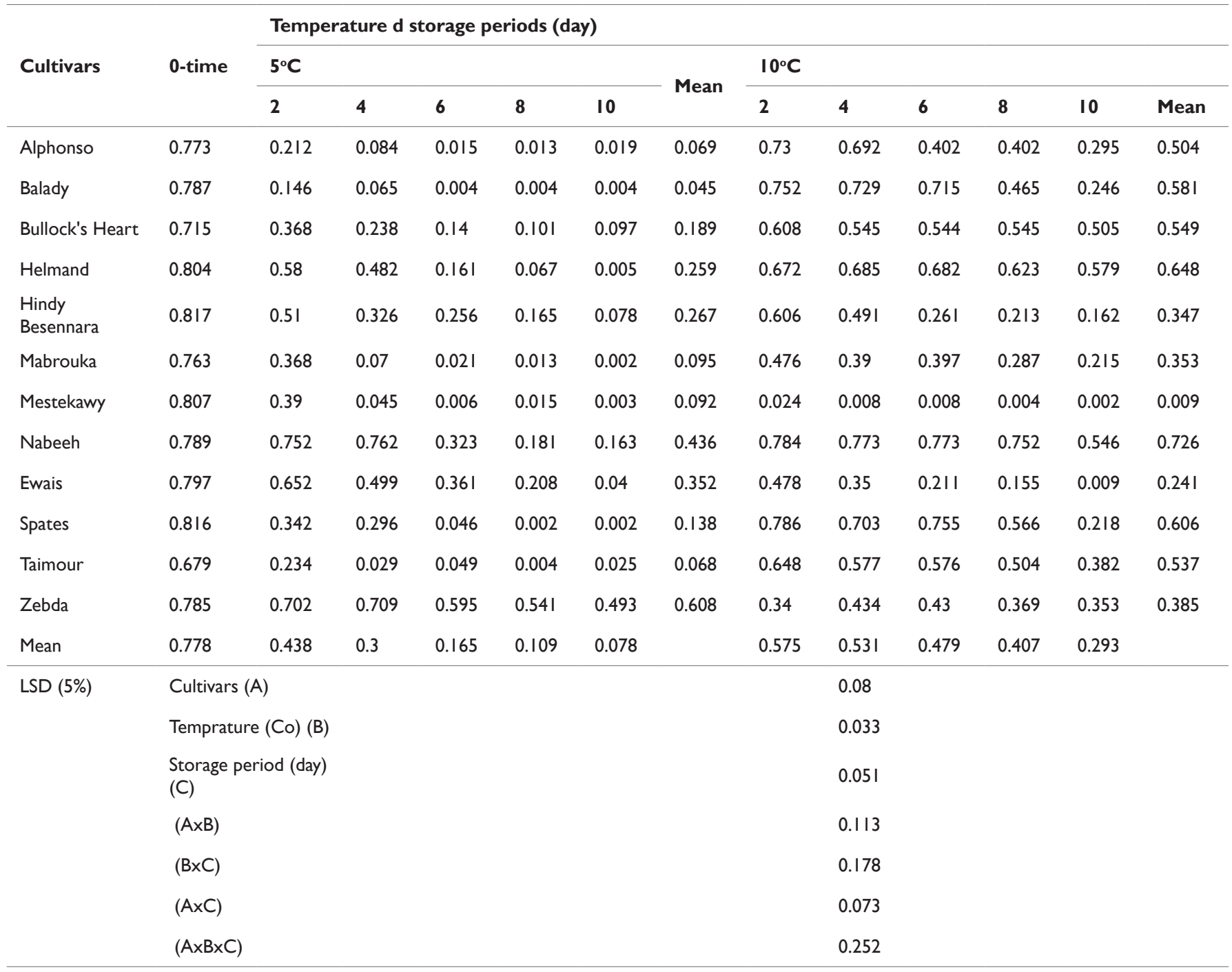




\section{Discussion}

Chilling temperatures (lower than $15^{\circ} \mathrm{C}$ ) lead to numerous physiological disturbances in the cells of chilling-sensitive plant and result in chilling injury and death of tropical and subtropical. ${ }^{50,51}$ Obviously, the problem of plant resistance to chilling temperature, which often occurs in spring and autumn in many countries, is important for practical plant breeding. A change in the Egyptian climate has already been observed during the last decades, and this is expected to continue throughout this century. This change in climate affects the behavior of fruit trees and their productivity. In 2008, Egypt was exposed to a wave of frost that caused severe damage to mango trees; Hence, there is a need to know which cultivars are resistant to winter cold. ${ }^{52}$

As a result of this sensitivity, low temperature produce a range of physiological and metabolic disorders that lead to serious losses. The various dysfunctions that arise under low temperature conditions result in various physical and metabolic changes that are easily scored and which can therefore be used to assess the degree of chilling injury. Thus, the aim of this trail is to study the change in leaf pigments and chlorophyll fluorescence as indicators for determine index of some mango cultivars and to know which of them are resistant to chilling temperatures.

\section{Leaf pigments}

In fresh leaf samples, the concentration of leaf pigments; chlorophyll a, b, total, carotenoids and anthocyanin increased in some cultivars than the others specially. Under cold storage conditions (Tables, 2, 3, 4, 5 and 6), the highest values of leaf pigments were given by the cultivars of Spates (Chl. a, b and total); Mabrouka and Zebda (carotenoids); Ewais (anthocyanin) at $5^{\circ} \mathrm{C}$. At $10^{\circ} \mathrm{C}$, the highest ones were recorded by the cultivars of Spates (Chl. a, b and total) and Zebda (carotenoids and anthocyanin). But the lowest ones by Mabrouka (Chl. a and total); Ewais (Chl. b); Bullock's Heart (carotenoids) and Zebda (anthocyanin) at $5^{\circ} \mathrm{C}$. In other words, at $10^{\circ} \mathrm{C}$, the lowest ones were estimated by Mabrouka (Chl. a, b and total); Helmand (carotenoids) and Alphonso (Anthocyanin).

Based on the previously obtained results the decrease in chlorophyll concentrations in some cultivars may be attributed to increase activity of chlorophyll-degrading enzyme chlorophyllase under low temperature stress conditions and may by inhibition of their biosynthesis. ${ }^{53}$ At low temperatures, the low chlorophyll content can be seen as an indication for a deficiency of photosynthetic capacity of the leaves. ${ }^{30,54}$ Partelli et al. ${ }^{42}$ showed that coffee plants resulted in $30 \%$ reduction in chlorophyll a, $27 \%$ reduction in chlorophyll b, $29 \%$ reduction of total chlorophyll when night temperature decreasing from $20^{\circ} \mathrm{C}$ to $8^{\circ} \mathrm{C}$ and by $50 \%$ reduction due to exposure to low temperature $\left(10^{\circ} \mathrm{C}\right)$ for 2 weeks. $^{15}$ Decrease of photosynthesis at chilling temperatures may be a consequence of photo-oxidative damage to the photosystems in the membranes of chloroplasts which is manifested by increased degradation of chlorophyll and carotenes. ${ }^{54}$ Carotenoids and consequently, chlorophyll $\mathrm{a}$ and $\mathrm{b}$ deplete after a lag time of 3 to 6 hours of exposure to low temperatures (Wise and Naylor, 1987).

The anthocyanin accumulate in leaves and stems in response to low temperatures. It has been reported that cold stress induces transcriptomic modification that increase flavonoid biosynthesis, including reactions involved in anthocyanin biosynthesis and metabolic pathways that supply it. It is conceivable that enhanced cold tolerance of plants may be partly be associated with increased activity of antioxidant system and photo-oxidation prevention from induced anthocyanins which accumulate in leaves under low temperatures. ${ }^{17}$

In fact, the low temperature in autumn induced an increase in the activity of phenylalanine ammonia-layse in persimmon shoots. The activity of this enzyme reached its maximum level during the period from autumn to winter. ${ }^{55}$ These results are in agreement with the findings of researchers; Luo and Wang ${ }^{56} \&$ Pennycooke et al. ${ }^{18}$

\section{Chlorophyll fluorescence (CF)}

The relationship between low temperature stress and the responses of different mango cultivars which tested in this study was monitored on changes in its fluorescence yields as expressed in $F v / F m$ through the application of a non-destructive technique-chlorophyll fluorescence.

$F v / F m$ values that were higher than 0.6 were classified as chilling tolerant and values starting from 0.5 and below as chilling sensitive. ${ }^{57}$ Hence, under field conditions, the all tested cultivars of mango are chilling tolerant with the highest value of $F v / F m$ by the cultivars of Mestekawy, Spates and Zebda and the lowest ones by the cultivar of Alphonso (Table 7). Additionally, the explosion of plants to low temperatures $\left(5^{\circ} \mathrm{C}\right.$ and $10^{\circ} \mathrm{C}$ ) (storage trail) which induce chilling injury causes a fast decrease in the $\mathrm{CF}$ value and a significant decrease in $F v /$ $\mathrm{Fm}$ values for all mango cultivars was observed during all the periods of cold storage at $5^{\circ} \mathrm{C}$ and $10^{\circ} \mathrm{C}$ (Table 7). This agrees with the onset of chilling injury in crops of tropical origin. ${ }^{57}$ Applying the previous standard $(F v / F m<0.6=$ chilling tolerant and $\leq 0.5=$ chilling sensitive $)$, the cultivar of Zebda and Nabeeh are chilling tolerant at $5^{\circ} \mathrm{C}$ and $10^{\circ} \mathrm{C}$, orderly, but Balady and Mestekawy ones are chilling sensitive. In this respect, the geographic of the mango cultivar influence the resulting changes in fluorescence yields. The genotype or the parental lines mango cultivars transfers traits that will be intensified upon exposure to low temperature stress, such as better ROS scavenging capacity or higher unsaturation of fatty acids. ${ }^{58}$ Decline in $F v / F m$ values were attributed to a rise in stomatal limitation of net $\mathrm{CO}_{2}$ assimilation rate and a decrease Rubisco activity. ${ }^{59}$ However, leaf detachment acts by hastering the decrease of chlorophyll as reported by Potvin ${ }^{60}$ while, studying its effects on bean, maize and cucumber. In this respect, $F v /$ $\mathrm{Fm}$ measurements from $0.78-0.85$ are associated with healthy, nonstressed delicious and evergreen trees ${ }^{24}$ or near $0.80 .{ }^{61}$

The $F v / F m$ ratios for leaves of mango trees were $0.80 \pm 0.03$, for indicating that photosynthetic processes were functioning normally in autumn. The $F v / F m$ ratios for mango tress were lower in winter when minimum daily temperatures decreased below $10^{\circ} \mathrm{C}$ compared to early splitting and degradation of the protein of PSII. ${ }^{33}$ The decline of CF under low-temperature stress was probably due to chlorophyll degradation and also to the degree of chloroplast membrane injury. ${ }^{62}$

Thus, the chlorophyll fluorescence provides a tool to classify the impact of low temperature on basic physiological processes. As such the method may improve the basis for genetic analysis of yield reduction due to low temperature treatments fall when chilling did not occur. ${ }^{27}$ The lower $F v / F m$ ratios indicated a reduced photochemical conversion efficiency of PSII ${ }^{28}$ which can be an effect of photoinhibition at chilling temperatures. ${ }^{29}$

The ratio of $F v / F m$ has an optimal value of 0.83 when exposed to abiotic and biotic stresses; $F v / F m$ in plants will decrease. ${ }^{40} \mathrm{This}$ parameter is therefore, frequently used as stress detector under environmental stress conditions, such as low temperature. ${ }^{41}$ Lowtemperature induced inhibition also involves reduced electron transfer 
via PSII due to down-regulation of water. The decrease in $F v / F m$ was associated with decreases in both $F 0$ and $F m$. these parameters represent the fluorescence yield when all reaction centers of PSII are open and closed, respectively. ${ }^{48}$ Decreases in $\mathrm{Fm}$ indicate an increase in heat formation in both the reaction center and antenna of PSII, ${ }^{63}$ whereas changes in $\mathrm{FO}$ are due to structural alterations in the thylakoid membranes. ${ }^{64-66}$

\section{Funding}

None.

\section{Acknowledgments}

None.

\section{Conflicts of interest}

Authors declare no conflict of interest exists.

\section{References}

1. Mitra SK, Baldwin EA. Mango In: Mitra SK. editor. Postharvest physiology and storage of tropical and subtropical fruits. $C A B$ International. New York, NY. 1997;85-122.

2. Alons G, Blaikie SJ. Seasonal variation of carbon assimilation in mango (cv. Kensington Pride): effect of flowering treatments. Australian Journal of Agriculture Research. 2003;54:309-321.

3. Schaffer B, Whiley AW, Grane JH. Mango. In- handbook of environmental physiology of fruit crops. Sub-Tropical and Tropical Crops. CRC Press Inc, Boca Raton, FL. USA; 1994;165-197.

4. Sharma S, Rao TVR. Responses of fresh-cut products of four mango cultivars under two different storage conditions. J Food Sci Technol. 2017;54(6):1689-1702.

5. Boyer JS. Plant productivity and environment. Science. 1982;218:443448.

6. Andersen UB, Kjaer KH, Erban A, et al. Impact of seasonal warming on overwintering and spring phenology of blackcurrant. Environmental \& Experimental Botany. 2017;140:96-109.

7. Huner NPA, Öquist G, Hurry VM, et al. Photosynthesis, Photoinhibition and low temperature acclimation in cold tolerant plants. Photosynth Res. 1993;37:19-39.

8. Schwachtje J, Whitcomb SJ, Firmino AAP, et al. Induced, imprinted, and primed responses to changing environments: does metabolism store and process information?. Frontiers in Plant Science. 2019;10:106.

9. Zuther E, Schaarschmidt S, Fischer A, et al. Molecular signatures associated with increased freezing tolerance due to low temperature memory in Arabidopsis. Plant Cell \& Environment. 2019;42:854-873.

10. Allen DJ, Ort DR. Impacts of chilling temperatures on photosynthesis in warm climate plants. Trends in Plant Science. 2001;6:36-42.

11. Gadallah FM, Seif El-Yazal MA, Abdel-Samad GA, et al. Physiological changes in leaves of some mango cultivars as response to exposure to low temperature degrees. Horticult Int J. 2019;3(6):266-273.

12. Farooq S, Azam F. The Co-existence of salt and drought tolerance in Triticaceae. Hereditas. 2002;135:205-210.

13. Vyse K, Pagter M, Zuther E, et al. Deacclimation after cold acclimation - a crucial, but widely neglected part of plant winter survival. Journal of Experimental Botany. 2019;70(18):4595-4604.

14. Partelli FL, Vieira HD, Viana AP, et al. Low temperature impact on photosynthetic parameters of coffee genotypes. Pesquisa Agropecuária Brasileira. 2009;44:1404-1415.

15. Aghaee A, Moradi F, Zare-maivan H, et al. Physiological responses of two rice (Oryza sativa L.) genotypes to chilling stress at seedling stage. African Journal of Biotechnology. 2011;10(39):7617-7621.

16. Leng P, Itamura H, Yamamura H, et al. Anthocyanin accumulation in apple and peach shoots during cold acclimation. Scientia Horticulturae. 2000;83:43-50.

17. Hao W, Arora R. Freezing tolerance and cold acclimation in guava (Psidium guajava L.). Hortscience. 2009;44(5):1258-1266.

18. Pennycooke JC, Cox S, Stushnoff, C. Relationship of cold acclimation, total phenolic content and antioxidant capacity with chilling tolerance in petunia (Petunia×hybrida). Environ Exp Bot. 2005;53:225-232.

19. Solecka D, Boudet AM, Kacperska A. Phenylpropanoid and anthocyanin changes in low-temperature treated winter oilseed rape leaves. Plant Physiol Biochem. 1999;37:491-496.

20. Öquist G, Hurry VM, Huner NPA. Low-temperature effects on photosynthesis and correlation with freezing tolerance in spring and winter cultivars of wheat and rye. Plant Physiol. 1993;101:245-250.

21. Smillie RM, Nott R, Hetherington SE, et al. Chilling injury and recovery in detached and attached leaves measured by chlorophyll fluorescence. Physiol Plant. 1987;69:419-428.

22. Baker NR. A possible role for photosystem II in environmental perturbations of photosynthesis. Plant Physiol. 1991;81:563-570.

23. Percival GC. The use of chlorophyll fluorescence to identify chemical and environmental stress in leaf tissue of three oak (quercus) species. $J$ Arboric. 2005;31(5):215-227.

24. Yamane Y, Shikanai T, Kashino Y, et al. Reduction of QA in the dark: Another cause of fluorescence $F_{O}$ increases by high temperatures in higher plants. Photosynthesis Res. 2000;63:23-34.

25. Percival GC, Fraser GA. The influence of powdery mildew infection on photosynthesis, chlorophyll fluorescence, leaf chlorophyll and carotenoid content of three woody species. Arboric J. 2002;26(4):333347.

26. Percival GC. Evaluation of physiological tests as predictors of young tree establishment and growth. J Arboric. 2004;30(2):80-92.

27. Öquist G, Wass R. A portable microprocessor operated instrument for measuring chlorophyll fluorescence kinetics in stress physiology. Plant Physiol. 1988;73:211-217.

28. Krause GG. Photoinhibition of photosynthesis. An evaluation of damaging and protective mechanisms. Plant Physiol. 1988;74:566-574.

29. Groom QJ, Baker NR, Long SP. Photoinhibition of holly (Ilex aquifolium) in the field during the winter. Plant Physiol. 1991;83:585-590.

30. Schapendonk AH, Dolstra O, Van Kooten O. The use of chlorophyll fluorescence as a screening method for cold tolerance in maize. Photosynthesis Research. 1989;20:235-247.

31. Dolstra O, Haalstra SR, Van der Putten PEL, et al. Genetic variation for resistance to low-temperature photoinhibition of photosynthesis in maize. Euphytica. 1994;80:85-93.

32. Gray GR, Savitch LV, Ivanov AG, et al. Photosystem II excitation pressure and development of resistance to photoinhibition. II. Adjustment of photosynthetic capacity in winter wheat and winter rye. Plant Physiol. 1996;110:61-71.

33. Krause GH, Weis E. Chlorophyll fluorescence and photosynthesis. The basics. Ann Rev Plant Physiol. 1991;42:313-349. 
34. Schreiber U, Bilger W. Rapid assessment of stress effects on plan leaves by chlorophyll fluorescence measurements. In: Tenhunen, JD \& Catarino FM, editors. Plant response to stress-functional analysis in mediterranean ecosystems. NATO Advanced Science Institute Series. Springer-Verlag, Berlin, Heidelberg, New York. 1987;27-53.

35. Maxwell K, Johnson GN. Chlorophyll fluorescence- a practical guide. $J$ Exp Bot. 2000;51:659-668.

36. Smillie RM, Nott R, Hetherington SE, et al. Chilling injury and recovery in detached and attached leaves measured by chlorophyll fluorescence. Physiol Plant. 1987;69:419-428.

37. Van Kooten O, Mensink MGJ, Otma EC, et al. Chilling damage of dark stored cucumbers (Cucumis sativus L.) affects the maximum quantum yield of photosystem 2. In: Murata N. editor. Progress in Photosynthesis Research, Vol. 4. Kluwer, Dordrecht. 1992;(4):161-164.

38. DeEll JR, Prange RK, Murr DP. Chlorophyll fluorescence of delicious apples at harvest as a potential predictor of superficial scald development during storage. Post Biol Tech. 1996;9:1-6.

39. Mir NA, Perez R, Beaudry RM. Chlorophyll fluorescence and whole fruit senescence in 'golden delicious' apple. Acta Hortic. 1998;464:121126.

40. Baker NR. Chlorophyll fluorescence: A probe of photosynthesis in vivo. Ann Rev Plant Bio. 2008;59:89-113.

41. Öquist G, Huner NPA. Effects of cold acclimation on the susceptibility of photosynthesis to photoinhibition in Scots pine and in winter and spring cereals: a fluorescence analysis. Funct Ecol. 1991;5:91-100.

42. Qin ZH, Zhang MH. Detection of rice sheath blight for in-season disease management using multispectral remote sensing. Int $J$ Appl Earth Observation Geoinf. 2005;7:115-114.

43. Ghassemi-Golezani K, Khomari S, Valizadeh M, et al. Changes in chlorophyll content and fluorescence of leaves of winter rapeseed affected by seedling vigor and cold acclimation duration. J Food Agric Environ. 2008;6:196-199.

44. Rapaczb M. Cold-deacclimation of oilseed rape (Brassica napus var oleifera) in response to fluctuating temperatures and photoperiod. Ann Bot London. 2002;89:543-549.

45. Pellett H, Gearhart M, Dirr M. Cold hardiness capability of woody ornamental plant taxa. J Ame Soc Hort Sci. 1981;106:239-243.

46. Arnon DI. Copper enzymes in isolated chloroplast. Polyphenol-oxidase in Beta Vulgaris L. plant Physiol. 1949;24:1-5.

47. Fuleki T, Francis FJ. Quantitative methods for anthocyanins: I Extraction and determination of total anthocyanin in cranberries. J Food Sci. 1968;3:72-77.

48. Van Kooten O, Snel JFH. The use of chlorophyll fluorescence nomenclature in plant stress physiology. Photosynth Res. 1990;25:147150 .

49. Snedecor GW, Cochran WG. Statistical Methods. 7th Ed., Iowa state press, Ames, IA, USA.1980;pp.401-403.

50. Lukatkin AS, Brazaitytė A, Bobinas C, et al. Chilling injury in chilling sensitive plants: a review. Žemdirbystè-Agriculture. 2012;99(2):111124.
51. Kjaer KH, Winde J, Petersen KK, et al. Cold declamation mechanisms and reclamation potential in flower buds of blackcurrant (Ribes nigrum) Physiologia Plantarum. 2018.

52. Ismail OM. Use of electrical conductivity as a tool for determining damage index of some mango cultivars. Inter J Plant \& Soil Sci. 2014;3(5):448-456.

53. Reddy MP, Vora AB. Changes in pigment composition, hill reaction activity and saccharide metabolism in Bajra (Pennistum typhoides $\mathrm{S} \& \mathrm{H}$ ) leaves under $\mathrm{NaCl}$ salinity. Photosynthesis. 1986;20:50-55.

54. Kingston-Smith $\mathrm{AH}$, Foyer $\mathrm{CH}$. Bundle-sheath proteins are more sensitive to oxidative damage than those of the mesophyll in maize leaves exposed to paraquat or low temperatures. $J$ Exper Bot. 2000;51(342):123-130.

55. Leng $\mathrm{P}$, Itamura $\mathrm{H}$, Yamamura $\mathrm{H}$. Changes of phenylalanine ammonialyase activity in twig tissues of two Diospyros species during cold acclimation. (in Japanese, with English abstract). Environ. Control in Biol. 1995;33:43-48.

56. Luo GH, Wang AG. The scavenging effect of plant polyphenolics on superoxide radicals. (in Chinese, with English abstract). J Tropical and Subtropical Bot. 1994;2:95-99.

57. Lao DL, Shiesh CC, Lin LH. Determination of chilling sensitivity of mango (Mangifera indica L.) leaves using chlorophyll fluorescence. Hort. NCHU. 2010;35(4):23-32.

58. Lyons JM, Wheaton TA, Pratt HK. Relationship between the physical nature of mitochondrial membranes and chilling sensitivity in plants. Plant Physiol. 1964;39:262-268.

59. Allen DJ, Ramer K. Giller YE, et al. An overnight chill induces a delayed inhibition of photosynthesis at midday in mango (Mangifera indica L.) J Exp Bot. 2000;51(352):1893-1902.

60. Potvin C. Effect of leaf detachment on chlorophyll fluorescence during chilling experiments. Plant Physiol. 1985;78:883-886.

61. Mohammed GH, Binder BD, Gillies SL. Chlorophyll fluorescence: a review of its practical forestry applications and instrumentation. Scand. J For Res. 1995;10:383-410.

62. Bron IU, Ribeiro RV, Azzolini M, et al. Chlorophyll fluorescence as a tool to evaluate the ripening of 'Golden' papaya fruit. Post Biol and Techn. 2004;33:163-173.

63. Schreiber U, Bilger W, Hormann H, et al. Chlorophyll fluorescence as a diagnostic tool: basics and some aspects of practical relevance. In: Ragavendra AS. editor. Photosynthesis: A Comprehensive Treatise. Cambridge University Press, Cambridge. 1998;320-336.

64. Kitao M, Lei TT, Koike T, et al.Temperature response and photoinhibition investigated by chlorophyll fluorescence measurements for four distinct species of dipterocarp trees. Plant Physiol. 2000;109:284-290.

65. Anderson JM, Chow WS, Park YI. The grand design of photosynthesis: acclimation of the photosynthetic apparatus to environmental cues. Photosynth Res. 1995;46:129-139.

66. Dexter ST. Effect of several environmental factors on the hardening of plants. Plant Physiol. 1993;8:123-139. 